\title{
HIV stigmatization and testing
}

\author{
Marianne Beaulieu $^{1 *}$, Alix Adrien ${ }^{2}$, Louise Potvin ${ }^{1}$, Clément Dassa $^{1}$ and Comité consultatif sur les attitudes envers les PVVIH \\ ${ }^{1}$ Ecole de santé publique, Université de Montréal, Montréal, Canada \\ ${ }^{2}$ Secteur Vigie et Protection, Agence de la santé et des services sociaux de Montréal, Montréal, Canada
}

\begin{abstract}
Objective: The purpose of this study was to assess the relationship between stigmatizing attitudes towards people living with HIV (PLHIV) and HIV testing.

Methods: A cross-sectional population study was conducted in the province of Quebec, Canada. A representative sample of 1,500 for the province Quebec randomly selected individuals aged 15 to 64 years and able to speak French or English was surveyed. Participants were interviewed by telephone from March to April 2010. Bivariate analyses and multiple sequential logistic regression analyses were performed to assess the relationship between stigmatizing attitudes and HIV testing while controlling for variables known to be associated with testing.

Results: Only $45 \%$ of the participants had ever been tested for HIV. Of these, $25 \%$ had been tested in the past 12 months and $55 \%$ in the past 5 years. Compared with never-tested participants, tested participants were more likely to be women, aged less than 50 years, born outside Canada, more educated, have engaged in risky behaviors, and have known at least one PLWHA. The mean stigmatizing attitude score was statistically nonsignificant in the multivariate model. However, considered separately, one attitudinal dimension showed significance. After adjusting for demographics and individual variables, being less concerned about occasional encounters with PLHIV significantly increased the odds for HIV testing (OR=1.31; 95\% CI: 1.06-1.61).
\end{abstract}

Conclusion: People expressing less concern about occasional encounters with PLHIV were more likely to have had HIV testing. This finding suggests a deleterious effect of stigmatization on HIV testing, and that this concern may be a critical consideration in designing awareness campaigns to encourage HIV testing.

\section{Key messages}

- More than half (55\%) of the participants had ever been tested for HIV.

- Taken as a whole, stigmatizing attitudes are not statistically related to HIV testing.

- People expressing more concern about occasional encounters with PLHIV are less likely to have had HIV testing.

\section{Introduction}

Almost one-quarter (25\%) of the 71,300 people in Canada living with HIV (PLHIV) are unaware that they are infected [1]. Early detection is key to preventing the spread of HIV [2]. Accordingly, delayed detection in the general population is a major problem, as it results in higher rates of transmission, morbidity, and mortality, along with substantial public health costs [3]. In addition, early diagnosis encourages individuals to adopt safer practices [4], and results in more effective and efficient medical care by reducing the infectivity of individuals with HIV [5], and therefore the risk of spreading the virus [6].

Many studies conducted in at-risk populations have attempted to explain the reasons why people get tested for HIV. The most commonly mentioned are demographics such as age, gender, ethnicity, religion, education, and marital status. These are generally followed by individual factors such as risky behaviors for HIV, perceptions of HIV risk, and knowledge about HIV [7-9]. A few studies have also identified clinical (previous sexually transmitted infections or history of HIV testing) and organizational factors that are associated with HIV testing [8-10]. In addition, social factors such as HIV-related stigmatization or discrimination have been proposed [10]. A recent meta-analysis comparing high- and low-income countries revealed that despite the many differences between the two locations, risky behaviors and stigmatization constitute universal determinants of HIV testing [11].

According to Canadian studies, despite the evident benefits of early HIV diagnosis and awareness campaigns designed to encourage testing, almost half the Canadian adult population has never been tested for HIV $[12,13]$. Although fewer in number than studies targeting specific at-risk groups, population studies in industrialized countries tend to show that HIV testing is associated with a variety of demographic characteristics [13-16]. Research on HIV testing has also considered individual factors such as a history of risky behaviors for HIV and being acquainted with a PLHIV are associated with HIV testing [1316]. However, an important variable is often overlooked: although individual factors and demographic characteristics are proximal determinants of health behaviors, other psychosocial factors, such as attitudes, can be associated with these behaviors [17]. Unfavorable attitudes are considered root causes of stigmatization [18].

Dovidio et al. [19] defined stigmatization as an intertwined mix of perspective (perceiver vs. target), identity (group-based vs. personal) and cognitive-affective-behavioral response. The current study is interested in the cognitive-affective-behavioral responses of perceivers. From a socio-cognitive perspective, stigmatization can be conceptualized as a mixture of attitudes (stereotypes, prejudices, discrimination) and values concerning PLHIV, but also as social distancing and support for coercive measures [20]. These attitudes play

Correspondence to: Marianne Beaulieu, Ecole de santé publique, Université de Montréal, Montréal, Canada, E-mail: beaulieu.marianne@gmail.com

Key words: HIV, public health, PLHIV

Received: July 22, 2017; Accepted: August 28, 2017; Published: August 30, 2017 
an important role in health behaviors, and they pose daunting obstacles to the implementation of preventive measures [21]. In this sense, it is argued that stigmatization acts as a catalyst for spreading HIV, because it discourages some people from getting tested for fear that the test will be positive [21]. Based on this widely accepted scientific argument, our hypothesis is that stigmatization is a barrier to HIV testing, above and beyond demographic characteristics [21]. Even though few studies have examined this relationship, it is imperative to gain a better understanding of the relationship between stigmatization and testing in the general population. This would help improve public health strategies and better target awareness campaigns. Therefore, using the data of an attitudinal survey, the objectives of this study were two-fold: (1) to determine the proportion of the population aged 15 to 64 years that has been tested for HIV; (2) to assess the relationship between stigmatizing attitudes and HIV testing while controlling for variables known to be associated with testing; and (3) to assess the association between components of stigmatizing attitudes and HIV testing while controlling for variables known to be associated with testing.

\section{Methods}

\section{Participants and survey methodology}

A provincially representative sample comprising 1,500 individuals living in all regions of the province of Quebec was surveyed. Participants were aged 15 to 64 years and spoke French or English (French-speaking $\mathrm{n}=1,040$; English-speaking $\mathrm{n}=460$ ). Participants were interviewed by telephone from March to April 2010, and the response rate was $73.5 \%$. Participants' telephone numbers were randomly selected using the ASDE Survey Sampler. Respondents were also randomly selected within households according to the individual whose birthday came next. The study protocol was approved by the ethics committee of the Faculty of Medicine of Université de Montréal (CERFM\#429) and of the Montreal Public Health governmental authority (CER\#225).

\section{Measures}

HIV testing. The dependent variable is a dichotomous measure: respondents reported whether they had been tested for HIV at least once in their lifetime $(\mathrm{no}=0$; yes $=1)$. Respondents who reported a prior HIV test were asked to indicate the year in which they had their most recent test to compute the time since the last HIV test (year of the interview - year of the most recent test). Two variables were then created: most recent test within 1 year $($ no $=0$; yes $=1)$; and most recent test within 5 years $($ no $=0$; yes $=1)$.

Stigmatizing attitudes towards people living with HIV/AIDS. To measure HIV stigmatization, we developed the Stigmatizing Attitudes towards People Living with HIV/AIDS Scale (SAT-PLWHA-S [22]). The SAT-PLWHA-S contains 27 items scored on a 4-point Likert scale, 1 (strongly disagree) to 4 (strongly agree). Items are coded such that a higher mean score indicates a more positive overall attitude. The scale has a seven-factor structure confirmed with structural equation modeling: 1-Concern about occasional encounters with PLHIV, 2-Fear of personal contact with PLHIV, 3- PLHIV Responsibility and blame, 4-Sexual liberalism, 5-Social support for PLHIV, 6- Confidentiality of seropositive status, and 7-Criminalization of HIV/AIDS transmission (Table 1). Scale reliability was estimated with Cronbach's alpha, which was high at $\alpha=0.88$. Single factor scores were subsequently determined as satisfactory $(\alpha=0.79-0.59)$.

Individual factors. Respondents were classified as being at increased risk for HIV (no=0; yes $=1$ ) if they reported having used injection drugs at least once in their lifetime (excluding those received in hospital)
Table 1. Stigmatizing Attitudes towards People Living with HIV/AIDS Scale.

\section{F1: Concerns about occasional encounters}

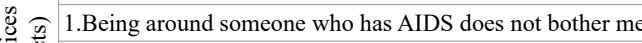

2.I would not be worried for my health if a co-worker had AIDS

3.It would not bother me if there was a boarding house for people with AIDS on my street.

\section{F2: Fear of personal contact}

$\stackrel{0}{:}$ :

承冚 5.I would limit my contact with a person whom I know is infected with AIDS. 6.I would not hug someone with AIDS.

F3: Responsibility and blame

7.People who use injectable drugs deserve to have AIDS

8.My support for a person living with AIDS depends on how the person was

कิ

9.I am disgusted by persons who were infected during homosexual relations.

递 condom deserve what they get.

29.People with AIDS have only themselves to blame.

39.Most people with AIDS are responsible for having their illness.

F4: Liberalism

10.To fight AIDS, it is necessary that young people not have sex.

$\stackrel{0}{\varrho} 11$. Reinforcement of traditional sexual values will help to control AIDS.

12.The arrival of AIDS is linked to the fact that people have more sexual freedom.

13.The spread of AIDS is linked to the decline of moral values.

\section{F5: Social support}

14.People who have AIDS should have the right to work serving the public, as waiters-waitresses, cooks, hairdressers

: 15 . Children who are infected with the aids virus should be able to go to day-care.

16.Doctors with AIDS should be allowed to go on working with their patients.

19.People infected with the aids virus should be allowed to immigrate to Canada. 23.If I had a roommate and discovered he was infected with the AIDS virus, it would not bother me.

F6: Confidentiality of serological status

27.I have the right to know if someone around me is infected with the AIDS virus.

32.When a screening test indicates that someone is infected with the AIDS virus,

the result should remain confidential.

41.Doctors should report the names of people with AIDS to the government.

F7: Criminalization of transmission

을 26 .Transmitting the AIDS virus should be punishable by law.

31.People who know they are infected with the AIDS virus and who transmit the virus are criminals.

34.Transmitting the AIDS virus is a crime.

and/or having had male-to-male sex at least once in their lifetime. Acquaintance with a PLHIV was also documented (ever known a PLHIV: no=0; yes=1).

Demographic characteristics. Demographic characteristics included gender $($ male $=0$; female $=1$ ), age (under 30 years $=1 ; 30$ to 49 years $=2 ; 50$ years and older $=3$ ), country of birth (outside Canada $=0$; Canada $=1$ ), education (fewer than 14 years $=0 ; 14$ years and more $=1$ ), residential status (rural=0; urban $=1$ ), and marital status (single $=0$; married/ partnered $=1$ ).

\section{Statistical analysis}

Post-stratification weighting was used to reconcile known differences between the sample data and the population's parameters. An iterative technique was used to balance the distributions of the weighting parameters in the sample according to specific criteria. Four criteria were use to derive the final weights (gender, region, language, age).

Analyses were performed in two stages. First, bivariate analyses (chi-square test and t-test) were run to derive the respondents' HIV 
testing profiles. All variables associated with the dependent variable (HIV testing) with a p-value $<0.20$ were used as independent variables.

Second, simple and multiple sequential logistic regression analyses were conducted to analyze the relationship between stigmatizing attitudes and HIV testing after controlling for variables known to be associated with testing. Variables were included in the statistical models based on empirical evidence and grouped into conceptual blocks. The order of variable entry was predetermined based on previous research. A three-step modeling procedure was used as follows: Step 1 demographics, Step 2 - individual characteristics, Step 3 - stigmatizing attitudes towards PLHIV and Step 4 - components of stigmatizing attitudes towards PLHIV. In order to control for demographics, demographic variables were entered in Step 1. Statistically significant variables in the model $(\mathrm{p} \leq 0.05)$ were retained for Step 2. In Step 2 , a similar approach was used to analyze respondents' individual characteristics (e.g., risky behaviors and acquaintance with a PLHIV). Only statistically significant variables in the model were retained for the next step. Because of the hierarchical relationship between stigmatizing attitudes towards PLHIV (total score - Step 3) and components of HIV stigmatisation (subscores - Step 4), was performed in different models. The final model was assessed by calculating the statistical significance of the change in log-likelihood ratio at each analysis step. All analyses were performed using SPSS v.17 statistical software (SPSS Inc., Chicago, IL).

\section{Results}

\section{Descriptive data}

The analyses presented in this study were performed on the responses of 1,362 participants (cases missing information on the SAT-PLWHA-S $(n=130)$ or on HIV testing $(n=8)$ were excluded). After weighting, the total sample comprised 1,377 participants. Table 2 presents a sample description. Average age of respondents was 41.5 years $(\mathrm{SD}=13.7)$, and 49.9\% were women. Most respondents were relatively well educated, with an average of 14.2 years of education $(\mathrm{SD}=3.4)$. Of the sample, $80.4 \%$ spoke French, indicating oversampling of non-French speakers, and $89.3 \%$ were born in Canada. Approximately one-quarter of the sample (26.1\%) knew a PLHIV, and only $6.6 \%$ had engaged in risky behaviors at least once in their lifetime (injection drug use and/or maleto-male sex).

\section{Proportion tested for HIV}

Of the 1,377 respondents, 625 (45.4\%) reported having been tested for HIV at least once, and of these, $25.1 \%$ had been tested within the past 12 months $(n=152)$ and $55.8 \%$ within the past 5 years $(n=337)$. Overall, women were more likely than men to have been tested $(53.9 \%$ vs $46.5 \%)$. The age group from 30 to 49 years contained the highest proportion of respondents who had been tested (56.4\% vs $32.6 \%$ ), with the age group 50 years and older having the lowest proportion $(24.5 \%$ vs $40.3 \%)$. Being born outside Canada (12.8\% vs $9.1 \%$ ) and having 14 years or more of education ( $64.4 \%$ vs $51.8 \%$ ) was associated with a greater proportion of respondents tested. Other factors associated with testing were a history of engaging in risky behaviors (9.3\% vs $4.4 \%)$ and acquaintance with a PLHIV (35.2\% vs $18.6 \%)$. No statistically significant relationship was found between either residential status and testing or marital status and testing.

\section{Logistic regression}

Simple logistic regression suggest that individuals who have more favorable attitudes towards PLHIV ( $\mathrm{p}=0.0001)$, are less concerned about occasional encounters $(\mathrm{p}=0.0001)$, have less fear of personal contact
Table 2. Respondent demographic profile.

\begin{tabular}{|c|c|c|c|c|}
\hline Variables & & $\begin{array}{c}\text { Total } \\
\mathbf{n}=\mathbf{1 3 7 7}\end{array}$ & $\begin{array}{l}\text { Never tested } \\
n=752\end{array}$ & $\begin{array}{c}\text { Tested } \\
\mathrm{n}=625\end{array}$ \\
\hline \multicolumn{5}{|l|}{ Gender** } \\
\hline Male (0) & \multirow{2}{*}{ n (\%) } & $690(50.1)$ & $402(53.5)$ & $288(46.1)$ \\
\hline Female (1) & & 687 (49.9) & $350(46.5)$ & $337(53.9)$ \\
\hline \multicolumn{5}{|l|}{ Age $^{* * *}$} \\
\hline Under 30 (1) & \multirow{3}{*}{ n (\%) } & $321(23.5)$ & $202(27.1)$ & $119(19.2)$ \\
\hline 30 to 49 (2) & & $593(43.4)$ & $243(32.6)$ & $350(56.4)$ \\
\hline 50 and older (3) & & $452(33.1)$ & $300(40.3)$ & $152(24.5)$ \\
\hline \multicolumn{5}{|l|}{ Language } \\
\hline French (1) & \multirow{3}{*}{ n (\%) } & $1107(80.4)$ & $599(79.7)$ & $508(81.3)$ \\
\hline English (2) & & $223(16.2)$ & $125(16.6)$ & $98(15.7)$ \\
\hline Other (3) & & $47(3.4)$ & $28(3.7)$ & $19(3.0)$ \\
\hline \multicolumn{5}{|l|}{ Country of birth* } \\
\hline Outside Canada (0) & \multirow{2}{*}{ n (\%) } & $148(10.8)$ & $68(9.1)$ & $80(12.8)$ \\
\hline Canada (1) & & $1228(89.2)$ & $683(90.9)$ & $545(87.2)$ \\
\hline \multicolumn{5}{|l|}{ Education*** } \\
\hline Less than 14 years $(0)$ & \multirow{2}{*}{ n (\%) } & $582(42.5)$ & $360(48.2)$ & $222(35.6)$ \\
\hline 14 years and more (1) & & $788(57.5)$ & $387(51.8)$ & $401(64.4)$ \\
\hline \multicolumn{5}{|l|}{ Residential status } \\
\hline Rural (0) & \multirow{2}{*}{ n (\%) } & $613(44.5)$ & $338(44.9)$ & $275(44.0)$ \\
\hline Urban (1) & & $764(55.5)$ & $414(55.1)$ & $350(56.0)$ \\
\hline \multicolumn{5}{|l|}{ Martial status } \\
\hline Single (0) & \multirow{2}{*}{ n $(\%)$} & $507(36.8)$ & $283(37.7)$ & $224(35.8)$ \\
\hline Partnered/married (1) & & $869(63.2)$ & $468(62.3)$ & $401(64.2)$ \\
\hline \multicolumn{5}{|l|}{$\begin{array}{l}\text { Lifetime risk } \\
\text { behavior*** }\end{array}$} \\
\hline No $(0)$ & \multirow{2}{*}{ n (\%) } & $1281(93.4)$ & 718 (95.6) & $563(90.7)$ \\
\hline Yes (1) & & $91(6.6)$ & $33(4.4)$ & $58(9.3)$ \\
\hline \multicolumn{5}{|l|}{$\begin{array}{l}\text { Acquaintance with a } \\
\text { PLWHA*** }\end{array}$} \\
\hline No $(0)$ & \multirow{2}{*}{ n $(\%)$} & $1017(73.9)$ & $612(81.4)$ & $405(64.8)$ \\
\hline Yes (1) & & $360(26.1)$ & $140(18.6)$ & $220(35.2)$ \\
\hline $\begin{array}{l}\text { Stigmatizing attitudes ( } 27 \\
\text { items)*** }\end{array}$ & M (s.d.) & $3.00(0.45)$ & $2.95(0.46)$ & $3.05(0.44)$ \\
\hline $\begin{array}{l}\text { Fewer concern about } \\
\text { occasional encounters } \\
\text { with PLHIV }(\mathrm{F} 1)^{* * *}\end{array}$ & M (s.d.) & $3.49(0.57)$ & $3.43(0.59)$ & $3.56(0.52)$ \\
\hline $\begin{array}{l}\text { Less fear of personal } \\
\text { contact with PLHIV } \\
(\mathrm{F} 2)^{* * *}\end{array}$ & M (s.d.) & $3.46(0.66)$ & $3.41(0.71)$ & $3.53(0.58)$ \\
\hline $\begin{array}{l}\text { Less PLHIV blame/ } \\
\text { responsibility (F3)*** }\end{array}$ & M (s.d.) & $3.29(0.59)$ & $3.23(0.60)$ & $3.35(0.58)$ \\
\hline $\begin{array}{l}\text { Sexual liberalism } \\
(\mathrm{F} 4)^{* * *}\end{array}$ & $M$ (s.d.) & $2.75(0.73)$ & $2.68(0.72)$ & $2.83(0.74)$ \\
\hline $\begin{array}{l}\text { Social support for PLHIV } \\
\text { (F5)** }\end{array}$ & M (s.d.) & $2.94(0.68)$ & $2.89(0.69)$ & $3.00(0.66)$ \\
\hline $\begin{array}{l}\text { Less support for } \\
\text { confidentiality of HIV } \\
\text { serological status (F6) }\end{array}$ & M (s.d.) & $2.44(0.74)$ & $2.42(0.71)$ & $2.46(0.78)$ \\
\hline $\begin{array}{l}\text { Less support for } \\
\text { Criminalization of HIV } \\
\text { transmission (F7) }\end{array}$ & M (s.d.) & $2.46(0.81)$ & $2.47(0.81)$ & $2.44(0.82)$ \\
\hline
\end{tabular}

( $\mathrm{p}=0.0001$ ), attribute less blame to PLHIV ( $\mathrm{p}=0.0001$ ), hold more liberal sexual values $(\mathrm{p}=0.0001)$, and are more supportive of PLHIV $(\mathrm{p}=0.002)$ are more likely to report that they had been tested for HIV. No statistically significant association was found between confidentiality of seropositive status and testing or between criminalization of HIV/AIDS transmission and testing.

A three-step sequential logistic regression analysis was conducted to examine factors associated with HIV testing. Stigmatizing attitudes towards PLHIV were used as determinants (Table 3 - Steps 1, 2, and 3). The results of Step 1 indicated that country of birth was not statistically 
Table 3. Frequency, odds and adjusted odds ratio for lifetime HIV testing.

\begin{tabular}{|c|c|c|c|c|c|}
\hline Variables & $\begin{array}{c}\text { Simple } \\
\text { logistic regression } \\
\text { OR }(95 \% \mathrm{CI})\end{array}$ & $\begin{array}{c}\text { Multiple } \\
\text { logistic regression } \\
\text { Step } 1 \\
\text { OR }(95 \% \text { CI })\end{array}$ & $\begin{array}{c}\text { Multiple } \\
\text { logistic regression } \\
\text { Step 2 } \\
\text { OR }(95 \% \text { CI })\end{array}$ & $\begin{array}{c}\text { Multiple } \\
\text { logistic regression } \\
\text { Step } 3 \\
\text { OR }(95 \% \text { CI })\end{array}$ & $\begin{array}{c}\text { Multiple } \\
\text { logistic regression } \\
\text { Step } 4 \\
\text { OR }(95 \% \text { CI })\end{array}$ \\
\hline \multicolumn{6}{|l|}{ Gender } \\
\hline Male & 1.0 & 1.0 & 1.0 & 1.0 & 1.0 \\
\hline Female & $1.34(1.08-1.66)$ & $1.29(1.03-1.61)$ & $1.37(1.08-1.73)$ & $1.35(1.07-1.70)$ & $1.33(1.05-1.68)$ \\
\hline \multicolumn{6}{|l|}{ Age } \\
\hline Under 30 & $1.16(0.86-1.57)$ & $1.20(0.88-1.62)$ & $1.45(1.06-1.99)$ & $1.41(1.02-1.94)$ & $1.39(1.01-1.91)$ \\
\hline 30 to 49 & $2.85(2.12-3.68)$ & $2.83(2.18-3.66)$ & $3.18(2.43-4.16)$ & $3.13(2.39-4.10)$ & $3.13(2.39-4.10)$ \\
\hline 50 and older & 1.0 & 1.0 & 1.0 & 1.0 & 1.0 \\
\hline \multicolumn{6}{|l|}{ Country of birth } \\
\hline Outside Canada & 1.0 & - & - & - & - \\
\hline Canada & $0.68(0.48-0.96)$ & - & - & - & - \\
\hline \multicolumn{6}{|l|}{ Education } \\
\hline Less than 14 years & 1.0 & 1.0 & 1.0 & 1.0 & 1.0 \\
\hline 14 years and more & $1.68(1.35-2.09)$ & $1.47(1.17-1.85)$ & $1.43(1.14-1.81)$ & $1.40(1.10-1.77)$ & $1.41(1.12-1.78)$ \\
\hline \multicolumn{6}{|l|}{ Residential status } \\
\hline Rural & 1.0 & - & - & - & - \\
\hline Urban & $1.04(0.84-1.29)$ & - & - & - & - \\
\hline \multicolumn{6}{|l|}{ Martial status } \\
\hline Single & 1.0 & - & - & - & - \\
\hline Partnered/married & $1.08(0.87-1.35)$ & - & - & - & - \\
\hline \multicolumn{6}{|l|}{ Lifetime risk behavior } \\
\hline No & 1.0 & - & 1.0 & 1.0 & 1.0 \\
\hline Yes & $2.30(1.47-3.57)$ & - & $2.88(1.77-4.69)$ & $2.80(1.72-4.56)$ & $2.80(1.72-4.55)$ \\
\hline \multicolumn{6}{|l|}{ Acquaintance with a PLWHA } \\
\hline No & 1.0 & - & 1.0 & 1.0 & 1.0 \\
\hline Yes & $2.38(1.86-3.05)$ & - & $2.29(1.76-2.99)$ & $2.23(1.71-2.92)$ & $2.20(1.68-2.87)$ \\
\hline $\begin{array}{l}\text { Stigmatizing attitudes ( } 27 \\
\text { items) }\end{array}$ & $1.65(1.30-2.10)$ & - & - & $1.19(0.91-1.55)$ & - \\
\hline $\begin{array}{l}\text { Fewer concern about } \\
\text { occasional encounters with } \\
\text { PLHIV (F1) }\end{array}$ & $1.53(1.26-1.85)$ & - & - & - & $1.31(1.06-1.61)$ \\
\hline $\begin{array}{l}\text { Less fear of personal contact } \\
\text { with PLHIV (F2) }\end{array}$ & $1.34(1.13-1.58)$ & - & - & - & - \\
\hline $\begin{array}{l}\text { Less PLHIV blame/ } \\
\text { responsibility (F3) }\end{array}$ & $1.45(1.21-1.75)$ & - & - & - & - \\
\hline Sexual liberalism (F4) & $1.34(1.16-1.55)$ & - & - & - & - \\
\hline $\begin{array}{l}\text { Social support for PLHIV } \\
\text { (F5) }\end{array}$ & $1.28(1.10-1.50)$ & - & - & - & - \\
\hline $\begin{array}{l}\text { Less support for } \\
\text { confidentiality of HIV } \\
\text { serological status (F6) }\end{array}$ & $1.07(0.93-1.24)$ & - & - & - & - \\
\hline $\begin{array}{l}\text { Less support for } \\
\text { criminalization of HIV } \\
\text { transmission (F7) }\end{array}$ & $0.95(0.83-1.08)$ & - & - & - & - \\
\hline -2 Log-likelihood & - & 1764.50 & 1703.27 & 1701.62 & 1696.957 \\
\hline
\end{tabular}

associated with HIV testing in the multiple model. It was therefore removed from the model. Step 1 also showed that demographics (gender, age, education) as a set distinguished between those who had and had not been tested for $\operatorname{HIV}\left[\chi^{2}(4, \mathrm{~N}=1333)=99.999, \mathrm{p}=0.0001\right]$. In Step 2, individual factors (risky behaviors and acquaintance with a PLHIV) were entered into the regression model. Demographics and individual factors as a set distinguished between those who had and had not been tested for HIV $\left[\chi^{2}(6, N=1333)=161.227, p=0.0001\right]$. The change in log-likelihood ratios was equal to $61.23, \mathrm{p}<0.05$, indicating a significantly improved model. In Step 3, stigmatizing attitudes towards PLHIV were entered into the analysis. A test of the full model against a constant only model was statistically significant, indicating that the predictors as a set distinguished between the tested and non-tested groups $\left[\chi^{2}(7, N=1333)=162.87, p=0.0001\right]$. However comparison of log-likelihood ratios for models with and without stigmatizing attitudes towards PLHIV showed no statistically significant improvement with the addition of the mean attitudinal score $\left[\chi^{2}(1, \mathrm{~N}=1333)=1.65\right.$, n.s. $]$. Moreover, taking potential confounding demographic variables and individual factors into account, stigmatizing attitudes towards PLHIV did not yield a statistically significant association with HIV testing ( $\mathrm{OR}=1.19$; 95\% CI : 0.91-1.55).

As stigmatization is a multidimensional construct, additional analyses were performed to separately consider each dimension of HIV stigmatization that was associated with testing in the bivariate analysis. Seven different logistic regression models were built to examine associations with HIV testing (data not presented here). The first model used concern about occasional encounters as a determinant of HIV testing (see Step 4 in Table 3). A test of the full model against a constant only model was statistically significant, indicating that the predictors 
as a set distinguished between those who had and had not been tested for $\operatorname{HIV}\left[\chi^{2}(7, N=1333)=167.54, p=0.0001\right]$. Comparison of loglikelihood ratios for models with and without concern about occasional encounters showed statistically significant improvement with the addition of this variable, $\left[\chi^{2}(1, \mathrm{~N}=1333)=6.31, \mathrm{p}<0.05\right]$. After adjusting for demographics and individual variables, being less concerned about occasional encounters significantly increased the odds for HIV testing $(\mathrm{OR}=1.31 ; 95 \% \mathrm{CI}: 1.06-1.61)$. Subsequent models including the mean scores for fear of personal contact, blame/responsibility, liberalism, and social support did not show a statistically significant improvement in log-likelihood ratios over Step 3 (data not presented here).

\section{Discussion}

The purpose of this study was to assess the relationship between stigmatizing attitudes towards PLHIV and testing. The consideration of the relationship between stigmatization and testing is innovative in that this relationship has not yet been tested in the general population of high-income countries. The results of the study show that greater concern about occasional encounters was related to a lower proportion of HIV testing in our sample. This finding indicates that stigmatization could have a deleterious effect on testing.

In a concentrated epidemic, such as in Canada, the general population has a small but important influence on spread of HIV, particularly given the increasing transmission rate through heterosexual contact [23]. Showing higher rate than in the United States (40\%) [14] but similar to a recent Canadian survey (47\%) [12], our results show that over half of Quebec adult population has never been tested (55\%). Our findings also indicate that the most HIV testing was reported by people who engaged in high-risk behaviors. This might be explained by the fact that Quebec offers anonymous HIV testing, an approach particularly effective for reaching high-risk groups [13]. Moreover, the predominant HIV testing approach in Canada is a "voluntary counseling and testing model" with an exception for pregnant women who are offered "a routine prenatal HIV screening test with an 'opt out' policy" [24]. This strategy requires notification that the test will be performed, and consent is inferred unless the patient declines.

Although most prevention and awareness campaigns are based on the assumption that HIV stigmatization is a barrier to testing [21], few empirical studies have attempted to explain this hypothetical relationship. The results on the simple relationship show that stigmatization appears to be a determinant of HIV testing, but is non-significant after controlling for confounding variables. To better understand this result, we examined the dimensions of stigmatization separately to assess their impact on testing. After controlling for confounding variables, concern about occasional encounters with PLHIV was shown to be associated with lower rates of HIV testing. A systematic literature review of population-based studies in highincome countries shows that the more that people are afraid of HIV, the less they get tested [15]. In addition, people who stigmatize PLHIV could be concerned about being stigmatized if they were to test positive, which could prevent them from getting tested [21]. It is also likely that they would not consider themselves part of an at-risk group for HIV (nor part of a highly stigmatized group, in their eyes), and would therefore not feel the need to get tested. Hence, implementing an optout approach to testing could be instrumental for reaching people who do not feel at risk for HIV. As a matter of fact, the Center for Disease Control revised its recommendation to advocate for routine voluntary HIV screening (opt-out) as a normal part of medical practice, similar to screening for other treatable conditions [25]. Moving away from the "AIDS exceptionalism" would help HIV to be considered like any other health condition, which would help tackle HIV stigmatization. An optout HIV testing strategy would also meet the needs of at-risk groups looking for non-stigmatizing and confidential services [26].

A further noteworthy finding, and consistent with other studies conducted in high-income countries $[15,16]$, is that the people who personally knew a PLHIV were also more likely to report HIV testing. This finding could be useful in designing more effective populationbased campaigns by putting a face on HIV instead of treating it anonymously. The use of interpersonal contacts with members of the stigmatized group appears to be a way to reduce intergroup prejudice [27]. This approach challenges public attitudes about stigmatized groups through direct interaction with these groups [28]. It could be done through mass media interventions which have shown immediate and overall effects on promoting HIV testing [29].

Although the results demonstrate that one form of HIV stigmatization (concern about occasional encounters) could be barrier to testing, this study has certain limitations. First, as is often the case with telephone surveys, the sample may have excluded people who do not have a residential landline phone [30]. Second, the results could have been affected by social desirability bias due to the socially sensitive topic. Thus, some respondents may have reported less stigmatizing attitudes towards PLHIV than they actually felt. Moreover, the survey was conducted to assess attitudes, not to examine HIV testing behaviors. Therefore, the results are based on secondary data analysis, which has only limited scope. Furthermore, HIV testing was self-reported, and the questionnaire items did not allow differentiating between voluntary and other types of testing (e.g., donating blood, research or insurance purposes). Nevertheless, a recent Canadian survey showed that only a small proportion of HIV testing was non-voluntary (47\% all types of testing vs. $35 \%$ voluntary testing [12]).

\section{Conclusion}

In conclusion, nearly half the general Quebec adult population has never been tested for HIV. HIV testing varies with individual demographics and factors. The findings also suggest that a specific form of HIV stigmatization, concern about occasional encounters with PLHIV, poses a barrier to testing in the general population. This concern could be a critical consideration in designing HIV awareness campaigns to encourage HIV testing in the general population.

\section{Acknowledgments}

The authors wish to thank Pr.Toby Datta, Pr. Sylvie Gendron, Dr. Geneviève Mercille, and Dr. Stephanie Alexander for their comments on preliminary versions of this article. This article was made possible by grants from the ministère de la Santé et des Services sociaux du Québec (survey funding) and the Canadian Institutes of Health Research (CIHR), the 4P Strategic Training Program, and the University Without Walls (doctoral grant, M.B.).

\section{References}

1. Public Health Agency of Canada (2012) Summary: Estimates of HIV Prevalence and Incidence in Canada, 2011. Ottawa, Canada: Public Health Agency of Canada.

2. Owen SM (2012) Testing for acute HIV infection: implications for treatment as prevention. Curr Opin HIV AIDS 7: 125-130. [Crossref]

3. Sanders GD, Bayoumi AM, Sundaram V, Bilir SP, Neukermans CP, et al. (2005) Costeffectiveness of screening for HIV in the era of highly active antiretroviral therapy. $N$ Engl J Med 352:570-585. [Crossref]

4. Gorbach PM, Drumright LN, Daar ES, Little SJ (2006) Transmission behaviors of recently HIV infected men who have sex with men. J Acquir Immune Defic Syndr 42 : 80-85. [Crossref] 
5. Porco TC, Martin JN, Page-Shafer KA, Cheng A, Charlebois E. et al. (2004) Decline in HIV infectivity following the introduction of highly active antiretroviral therapy. AIDS 18:81-88.

6. Castilla J, del Romero J, Hernando V, Marincovich B, García S, et al. (2005) Effectiveness of highly active antiretroviral therapy in reducing heterosexual transmission of HIV. J Acquir Immune Defic Syndr 40: 96-101. [Crossref]

7. Ehrlich SF, Organista KC, Oman D (2007) Migrant Latino day laborers and intentions to test for HIV. AIDS Behav 11: 743-752. [Crossref]

8. MacKellar DA, Valleroy LA, Anderson JE, Behel S, Secura GM, et al. (2006) Recent HIV testing among young men who have sex with men: correlates, contexts, and HIV seroconversion. Sex Transm Dis 33: 183-192. [Crossref]

9. Tolou-Shams M, Payne N, Houck C, Pugatch D, Beausoleil N, et al. (2007) HIV testing among at-risk adolescents and young adults: a prospective analysis of a community sample. J Adolesc Health 41: 586-593. [Crossref]

10. Mounier-Jack S, Nielsen S, Coker RJ (2008) HIV testing strategies across European countries. HIV Med 9 Suppl 2: 13-19. [Crossref]

11. Gari S, Doig-Acuña C, Smail T, Malungo JR, Martin-Hilber A, et al. (2013) Access to HIV/AIDS care: a systematic review of socio-cultural determinants in low and high income countries. BMC Health Serv Res 13:198. [Crossref]

12. Calzavara L, Allman D, Worthington C (2012) HIV and AIDS in Canada: A National Survey. Canadian Association HIV/AIDS Research Conference Ancillary Session, Montréal.

13. Houston S, Archibald CP, Strike C, Sutherland D (1998) Factors associated with HIV testing among Canadians: results of a population-based survey. Int J STD AIDS 9: 341346. [Crossref]

14. Du P, Camacho F, Zurlo J, Lengerich EJ (2011) Human immunodeficiency virus testing behaviors among US adults: the roles of individual factors, legislative status, and public health resources. Sex Transm Dis 38: 858-864.

15. Kaai S, Bullock S, Burchell AN, Major C (2012) Factors that affect HIV testing and counseling services among heterosexuals in Canada and the United Kingdom: An integrated review, Patient Education and Counseling 88: 4-15.

16. Renzi C, Zantedeschi E, Signorelli C, Osborn JF (2001) Factors associated with HIV testing: results from an Italian General Population Survey. Prev Med 32: 40-48. [Crossref]
17. Ajzen I (2011) The theory of planned behaviour: reactions and reflections. Psychol Health 26: 1113-1127. [Crossref]

18. Link BG, Phelan JC (2001) Conceptualizing stigma. Annu Rev Sociol 27: 363-385.

19. Dovidio JF, Major B, Crocker J (2000) Stigma Introduction and overview. In T.F. Heatherton, R.E. Kleck, M.R. Hebl \& J.G. Hull (Eds.), The Social Psychology of Stigma Pp: 1-28.

20. Earnshaw VA, Chaudoir SR (2009) From conceptualizing to measuring HIV stigma: a review of HIV stigma mechanism measures. AIDS Behav 13: 1160-1177. [Crossref]

21. Herek GM, Capitanio JP, Widaman KF (2003) Stigma, social risk, and health policy: Public attitudes toward HIV surveillance policies and the social construction of illness Health Psychology 22: 533-540.

22. Beaulieu M, Adrien A, Potvin L, Dassa C; Comité consultatif sur les attitudes envers les PVVIH (2014) Stigmatizing attitudes towards people living with HIV/AIDS: validation of a measurement scale. BMC Public Health 14: 1246. [Crossref]

23. Lansky A, Drake A, DiNenno E, Lee CW (2007) HIV Behavioral Surveillance Among the U.S. General Population. Public Health Rep 122(Suppl.1): 24-31.

24. Samson L, King S (1998) Evidence-based guidelines for universal counselling and offering of HIV testing in pregnancy in Canada. CMAJ 158: 1449-1457. [Crossref]

25. Centers for Disease Control and Prevention (2006) Revised recommendations for HIV testing of adults, adolescents and pregnant women in health-care settings. MMWR 2006; 55(RR-14): 1-16.

26. Lorenc T, Marrero-Guillamon I, Llewellyn A, Aggleton P, Cooper C, et al. (2011) HIV testing among men who have sex with men; systematic review of qualitative evidence. Health Educ Res 26: 834-846.

27. Pettigrew TF, Tropp LR (2000) Does intergroup contact reduce prejudice? Recent meta-analytic findings. In S. Oskamp (Ed.) Reducing prejudice and discrimination. 'The Claremont Symposium on Applied Social Psychology’ (pp.93-114). Mahwah, NJ Lawrence Erlbaum.

28. Corrigan PW, Penn DL (1999) Lessons from social psychology on discrediting psychiatric stigma. Am Psychol 54: 765-776. [Crossref]

29. Vidanapathirana J, Abramson MJ, Forbes A, Fairley C (2005) Mass media interventions for promoting HIV testing. Cochrane Database Syst Rev: CD004775. [Crossref]

30. Kempf AM, Remington PL (2007) New challenges for telephone survey research in the twenty-first century. Annu Rev Public Health 28: 113-126. [Crossref]

Copyright: $(02017$ Beaulieu M. This is an open-access article distributed under the terms of the Creative Commons Attribution License, which permits unrestricted use, distribution, and reproduction in any medium, provided the original author and source are credited. 